\title{
PEMODELAN PRODUKSI TANAMAN KARET BERDASARKAN POTENSI KLON, TANAH, DAN IKLIM
}

\author{
Modelling of Hevea Production Based on Clone Potency, Soil, and Climate
}

\author{
Imam SUSETYO dan Hananto HADI \\ Balai Penelitian Getas, Pusat Penelitian Karet \\ Jl. Pattimura KM 6, Kotak Pos 804, Salatiga, Jawa Tengah
}

Diterima tanggal 17 April 2012 / Disetujui tanggal 11 Juli 2012

\begin{abstract}
According to soil plant relationship, there are close relationship between soil suitability and rainfall factor. Every crop requires specific soil and climate conditions for optimum growth. According to soil-plant relationship, there are close relationship between soil suitability and rainfall factor. Eventhough the influence of rainfall on plant growth depends on its distribution and soil type, commonly rainfall and plant production have a strong relationship. Rubber tree (Hevea brasiliensis) is indigenous to the tropical rain forest in the Amazon Basin, at an altitude of $200 \mathrm{~m}$ above mean sea level and near the equator. This region is characterised by monthly mean temperature between 24 and $28^{\circ} \mathrm{C}$, with average rainfall of annual totals amounting to $1500-2500 \mathrm{~mm}$ including some dry spells. Recently to decide land quality according to rubber productivity has still used qualitative methods with many versions. Quantitative research on predicting rubber production concerning clone potential, soil, and climate is stiil rare. The aim of this research was to find out the model of rubber tree production based on clone potential productivity, climate (rainfall, rainy day, altitude, and dry season) and soil (clay fraction, internal drainage). The asumption of all regression used was fitted line plot based on regression quadratic type model. The results showed that average optimum value for rainfall, rainy day, dry month, altitude, clay fraction (\%), and internal drainage class concerning rubber productivity were 2640 $\mathrm{mm} /$ year, 133 rainy days/year, 3 month/ year, and 168 above sea level, $55 \%$, and 3 (internal drainage classes based on USDA Handbook). These results showed that mathematic equation could be used to predict rubber production in specific area with accuracy level of $79.19 \%$.
\end{abstract}

Keywords: Hevea brasiliensis, production model, natural rubber

\section{Abstrak}

Tiap jenis tanaman menghendaki syarat iklim dan tanah tertentu bagi pertumbuhan optimalnya. Menyangkut hubungan tanah-tanaman, terdapat hubungan erat antara keserasian tanah dengan faktorfaktor curah hujan. Walaupun pengaruh curah hujan terhadap pertumbuhan tanaman amat bergantung pada penyebaran dan tipe tanahnya, curah hujan dan produksi tanaman mempunyai hubungan umum yang sangat kuat. Tanaman karet merupakan salah satu jenis tanaman hutan asli di lembah Amazon dengan ketinggian $200 \mathrm{~m}$ di atas permukaan laut (dpl) dan dekat dengan ekuator. Daerah ini memiliki karateristik suhu antara 24 sampai dengan $28^{\circ} \mathrm{C}$ dengan curah hujan rerata $1500-2500$ $\mathrm{mm} /$ tahun. Selama ini penentuan kualitas lahan kaitannya dengan produksi tanaman karet masih bersifat kualitatif dengan berbagai macam versi. Penelitian mengenai hubungan antara potensi klon, tanah, dan iklim dengan produksi tanaman karet secara kuantitatif belum banyak dilakukan. Tujuan penelitian ini adalah untuk mengetahui model potensi produksi karet klon tertentu pada wilayah dengan karateristik tanah dan iklim tertentu (spesifik wilayah). Asumsi yang digunakan untuk menentukan nilai optimal masing-masing adalah mengunakan persamaan regresi tipe kuadratik (regression quadratic model). Hasil penelitian menunjukkan hasil optimal untuk pertumbuhan tanaman adalah sebagai berikut yaitu 2640 $\mathrm{mm}$ curah hujan per tahun, 133 hari hujan pertahun, 3 bulan kering per tahun, $168 \mathrm{~m}$ dpl, 55\% jumlah fraksi lempung, dan drainase kriteria ke-3 atau well drained. Hasil ini menunjukkan bahwa penggunaan persamaan matematik dapat digunakan untuk menentukan potensi klon tertentu pada suatu wilayah dengan cepat dengan tingkat akurasi $79,19 \%$.

Keywords: Hevea brasiliensis, model produksi, karet alam 


\section{PENDAHULUAN}

Sumber daya alam merupakan tulang punggung perekonomian Indonesia dan diharapkan sektor pertanian, perikanan, dan kehutanan dapat berkembang lebih baik untuk menunjang sektor lain untuk pembangunan negara. Oleh karena itu, pemerintah mencanangkan Revitalisasi Pertanian, Perikanan, dan Kehutanan yang programnya diluncurkan pada Oktober tahun 2005. Karet secara keseluruhan (termasuk karet alam) merupakan kebutuhan vital yang tidak tergantikan dalam kehidupan sehari-hari. Diantara sekian puluh jenis karet (elastomer), karet alam tetap merupakan jenis elastomer yang paling besar konsumsinya di seluruh dunia, yaitu sekitar 40\%. Dengan melonjaknya harga minyak bumi akhir-akhir ini (sumber bahan olah karet sintetis) dan keunggulan dalam pelestarian lingkungan hidup, diharapkan bahwa proporsi karet alam akan meningkat menjadi 50\% (Budiman, 2005). Pertanaman karet saat ini mencapai luasan 3,2 juta ha yang terdiri atas Perkebunan Rakyat $(85,3 \%)$, Perkebunan Negara $(6,5 \%)$ dan Perkebunan Swasta $(8,2 \%)$ dengan produksi yang dihasilkan secara nasional mencapai sebesar 2,066 juta ton. Berdasarkan hasil studi LMC cit Budiman (2005) Indonesia merupakan wilayah dengan potensi produksi lebih tinggi dibanding Thailand, Malaysia, maupun India. Selain itu pengembangan area perkebunan karet Indonesia nomor dua terluas sesudah Thailand. Hal ini menunjukkan bahwa secara umum Indonesia merupakan daerah yang paling potensial dikembangkan baik dari segi produktivitas maupun area di tingkat dunia maupun asia.

Tiap jenis tanaman menghendaki syarat iklim tertentu bagi pertumbuhan optimalnya. Menyangkut hubungan tanahtanaman, terdapat hubungan erat antara keserasian tanah dengan faktor-faktor curah hujan, penyebaran hujan, dan defisit kejenuhan lengas udara. Walaupun pengaruh curah hujan terhadap pertumbuhan tanaman amat bergantung pada penyebarannya dan tipe tanahnya, hubungan antara curah hujan dengan produksi tanaman umumnya sangat kuat (William dan Joseph, 1974). Tanaman karet merupakan salah satu jenis tanaman hutan asli di lembah amazon dengan ketinggian
$200 \mathrm{~m}$ dpl dan dekat dengan ekuator. Daerah ini memiliki karateristik suhu antara 24 sampai dengan $28^{\circ} \mathrm{C}$ dengan curah hujan rerata 1500 - $2500 \mathrm{~mm} /$ tahun (Rao et. al., 1990). Menurut (Rao et al., 1993) area karet berproduksi tinggi biasanya ditemukan pada daerah dengan pola curah hujan yang cukup dan merata serta rendahnya fluktuasi suhu dan kelembaban selama 1 tahun. Pentingnya proses seleksi suatu tanaman yang akan ditanam di daerah yang bersifat dari sesuai sampai dengan marjinal telah dikemukakan oleh Ceccarelli (1994).

Estimasi spesifik adaptasi secara normal berdasarkan interaksi genetik dan lingkungan (Genetic-Enviroment (GE)). Walaupun produksi suatu tanaman merupakan salah satu faktor yang dievaluasi pada proses interaksi GE, hal ini tidak selalu berkait dengan kontrol genetik saja tetapi terbentuk dari proses interaksi antar genotipe (Genotype-Genotype (GG)) dan genotipe dan lingkungan ((GeneticEnviroment (GE)) seperti pada gen spesifik yang dikontrol oleh proses fisiologis dan biokhemis. Pada tanaman karet proses ini terbilang cukup kompleks karena hasil panennya adalah lateks (Priyadarshan, 2003b).

Penilaian lahan merupakan proses menaksir potensi lahan untuk suatu atau beberapa macam penggunaan alternatif. Pengembangan model kesesuaian lahan untuk perencanaan merupakan salah satu hal penting yang harus terus dikembangkan agar pemanfaatan lahan dapat optimal dan sesuai dengan fungsinya (Van Rast, 1997). Tingkat akurasi evaluasi lahan pertanian sangat tergantung pada parameterparameter yang dipilih serta hubungannya dengan produksi tanaman (Tang dan Van Rant, 1992).

Setelah lahan perkebunan dapat dipilah-pilah menjadi beberapa jenis (seri atau fase) tanah dengan cara survei/ pemetaan tanah, masing-masing jenis tanah perlu dinilai mutunya untuk optimisasi penggunaannya. Sugiyanto et al., (1998), menyebutkan bahwa konsep agroekosistem yang dapat disetarakan dengan konsep lahan mengandung tiga komponen utama yaitu tanah, iklim, dan tanaman. Dengan mempertimbangkan keadaan agroekosistem, penggunaan lahan berupa sistem 
produksi dan pilihan-pilihan tanaman yang tepat dapat ditentukan. Pengembangan areal tanaman karet baik yang sudah ada ataupun yang akan dilakukan pada masa yang akan datang hendaknya dilakukan di daerah yang mampu mendukung pertumbuhan secara normal dan memungkinkan dipertahankan kerapatan tanaman lebih dari 350 pohon/ha pada umur lebih dari 15 tahun sehingga risiko kegagalan rendah. Wilayah pengembangan karet yang mengalami serangan penyakit daun berkepanjangan, curah hujan tahunan > $3500 \mathrm{~mm} /$ th, umumnya terjadi pada daerah merata sepanjang tahun (tidak ada musim kering). Curah hujan tahunan yang tinggi dan merata sepanjang tahun akan menyebabkan tingginya kelembaban nisbi udara, keadaan ini sangat mendukung perkembangan patogen yang menyebabkan penyakit daun karet.

Sejumlah hasil pengamatan pertumbuhan dan produksi tanaman karet telah membuktikan bahwa tanaman karet sangat sesuai di wilayah bercurah hujan 1600 $2500 \mathrm{~mm} /$ th, dengan $2-4$ bulan kering, dan angin tidak menjadi kendala utama. Curah hujan setahun minimum untuk tanaman karet di Indonesia adalah $1500 \mathrm{~mm}$ dengan penyebaran merata, optimal antara 2500 $4000 \mathrm{~mm}$ selama 100 sampai 150 hari setahun (Dijikman, 1951). Menurut Jacob et al. (1989) jumlah curah hujan tahunan dan distribusinya sangat mempengaruhi produksi lateks tanaman karet sebab pada musim penghujan dan kemarau terjadi perbedaan lengas di dalam tanah. Hasil penelitian Aidi-Daslin et al. (1997) pada evaluasi terhadap 11 klon karet di 15 lokasi yang mewakili zona agroekologi perkebunan berdasarkan rata-rata curah hujan tahunan dan periode bulan kering menunjukkan bahwa terdapat perbedaan produktivitas di antara klon dan diantara lokasi dengan berbagai kondisi agroklimat. Produksi kumulatif tertinggi berturut-turut diperoleh pada penanaman di lahan beriklim sedang dan kering. Semua klon memperlihatkan produksi terendah pada penanaman di lokasi dengan kondisi agroklimat basah. Rendahnya produktivitas kebun karet pada lahan beriklim basah berkaitan dengan tingkat kepekaan klon terhadap penyakit gugur daun. Kondisi lahan dengan iklim basah tanpa bulan kering yang tegas ternyata mendukung perkembangan penyakit secara berkelanjutan dan terganggunya kegiatan penyadapan. Wilayah pengembangan karet akan lebih baik ke daerah yang memililki rata-rata curah hujan $1500-2000 \mathrm{~mm} /$ tahun dengan distribusi merata atau $2000-3000 \mathrm{~mm} /$ tahun dengan periode bulan kering yang tegas $1-2$ bulan. Penilaian lahan untuk produksi tanaman karet secara kuantitatif belum pernah dilakukan. Penelitian ini bertujuan untuk membuat model dan memprediksi potensi tanaman karet berdasarkan jenis (klon) pada suatu lahan (tanah dan iklim) tertentu pada daerah spesifik.

\section{BAHAN DAN METODE}

Bahan yang digunakan adalah data sekunder produksi tanaman karet pada iklim dan seri tanah tertentu. Data rerata iklim (curah hujan, hari hujan, bulan kering, dan ketinggian) diambil dari hasil penelitian Sudiharto (2004) sedangkan data tanah (persentase fraksi lempung dan drainase) diambil dari hasil penelitian Chan et al. (1974) dan Yew et al. (1991). Metode yang digunakan untuk mengestimasi kondisi fisik pada hasil yang optimal adalah sistem regresi tipe kuadratik (quadratic regression model) dengan asumsi bahwa sistem penyadapan dan pemeliharaan tanaman berlangsung sesuai dengan norma. Setelah persamaan masing-masing faktor dan nilai maksimal telah diketahui, kemudian disesuaikan dengan potensi produksi masing-masing klon. Klon yang digunakan dalam penelitian ini adalah GT 1. Untuk mengetahui produksi per tahun (asumsi norma kulit adalah 25 tahun) dikorelasikan dengan penelitian sebelumnya yang dilakukan Sutardi (1974). Setelah didapatkan persamaan masing-masing berdasarkan potensi klon data produksi kemudian diverifikasi menggunakan data produksi sesungguhnya. Verifikasi data ditentukan dengan cara mencari data sekunder tanah, iklim, dan produksi pada suatu kebun tertentu. Data tanah dan iklim didapatkan dari laporan pemetaan tanah detail yang pernah dilakukan. Penentuan bulan kering dilakukan berdasarkan metode SchmidthFergusson (1951), sedangkan untuk persentase lempung yang digunakan adalah data pada kedalaman $0-30 \mathrm{~cm}$. Hal ini dilakukan sesuai hasil penelitian Dea et al. (2001) 
menyebutkan bahwa yang melakukan penelitian berbagai pengolahan tanah pada awal penanaman akar rambut atau akar lateral paling banyak ditemukan pada kedalaman $0-30 \mathrm{~cm}$ dan prosentasenya semakin ke bawah semakin menurun. Perbedaan jumlah akar ini kemungkinan disebabkan oleh aerasi tanah, pergerakan lengas tanah, dan penetrasi akar (Boyer cit. Dea et al., 2001). Selain itu Rao et al. (2007) menyatakan bahwa lapisan tanah efektif yang mempengaruhi pertumbuhan tanaman karet adalah kedalaman $0-11 \mathrm{~cm}$ terutama pada tahun ke-2 sampai dengan tahun ke-7. Penentuan drainase tanah ditentukan berdasarkan acuan Ritung et al. (2007) yang membagi pola drainase tanah menjadi tujuh bagian dan disajikan pada Tabel 1 . Kemudian hasil perhitungan estimasi dibandingkan dengan realita sehingga didapatkan angka akurasi dengan cara : Nilai akurasi $=100-($ Produksi Estimasi Produksi Realita]/ Produksi Realita) x 100\%).

Tabel 1. Karakteristik kelas drainase tanah Table 1. Characteristics of the soil drainage class

\begin{tabular}{|c|c|c|}
\hline No & $\begin{array}{l}\text { Kelas drainase } \\
\text { Drainage class }\end{array}$ & $\begin{array}{c}\text { Uraian } \\
\text { Description }\end{array}$ \\
\hline 1 & $\begin{array}{l}\text { Cepat } \\
\text { (excessively } \\
\text { drained) }\end{array}$ & $\begin{array}{l}\text { Tanah mempunyai konduktivitas hidrolik tinggi sampai sangat tinggi dan daya } \\
\text { menahan air rendah. Tanah demikian tidak cocok untuk tanaman tanpa } \\
\text { irigasi. Ciri yang dapat diketahui di lapangan, yaitu tanah berwarna homogen } \\
\text { tanpa bercak atau karatan besidan aluminium serta warna gley (reduksi). }\end{array}$ \\
\hline 2 & $\begin{array}{l}\text { Agak cepat } \\
\text { (somewhat } \\
\text { excessively } \\
\text { drained) }\end{array}$ & $\begin{array}{l}\text { Tanah mempunyai konduktivitas hidrolik tinggi dan daya menahan air rendah. } \\
\text { Tanah demikian hanya cocok untuk sebagian tanaman kalau tanpa irigasi. Ciri } \\
\text { yang dapat diketahui di lapangan, yaitu tanah berwarna homogen tanpa } \\
\text { bercak atau karatan besidan aluminium serta warna gley (reduksi). }\end{array}$ \\
\hline 3 & $\begin{array}{l}\text { Baik } \\
\text { (well drained) }\end{array}$ & $\begin{array}{l}\text { Tanah mempunyai konduktivitas hidrolik sedang dan daya menahan air } \\
\text { sedang, lembab, tapi tidak cukup basah dekat permukaan. Tanah demikian } \\
\text { cocok untuk berbagai tanaman. Ciri yang dapat diketahui di lapangan, yaitu } \\
\text { tanah berwarna homogen tanpa bercak atau karatan besi dan/atau mangan } \\
\text { serta warna gley (reduksi) pada lapisan } 0 \text { sampai } 100 \mathrm{~cm} \text {. }\end{array}$ \\
\hline 4 & $\begin{array}{l}\text { Agak baik } \\
\text { (moderately well } \\
\text { drained) }\end{array}$ & $\begin{array}{l}\text { Tanah mempunyai konduktivitas hidrolik sedang sampai agak rendah dan } \\
\text { daya menahan air (pori air tersedia) rendah, tanah basah dekat permukaan. } \\
\text { Tanah demikian cocok untuk berbagai tanaman. Ciri yang dapat diketahui di } \\
\text { lapangan, yaitu tanah berwarna homogen tanpa bercak atau karatan besi } \\
\text { dan/atau mangan serta warna gley (reduksi) pada lapisan } 0 \text { sampai } 50 \mathrm{~cm} \text {. }\end{array}$ \\
\hline 5 & $\begin{array}{l}\text { Agak terhambat } \\
\text { (somewhat poorly } \\
\text { drained) }\end{array}$ & $\begin{array}{l}\text { Tanah mempunyai konduktivitas hidrolik agak rendah dan daya menahan air } \\
\text { (pori air tersedia) rendah sampai sangat rendah, tanah basah sampai ke } \\
\text { permukaan. Tanah demikian cocok untuk padi sawah dan sebagian kecil } \\
\text { tanaman lainnya. Ciri yang dapat diketahui di lapangan, yaitu tanah berwarna } \\
\text { homogen tanpa bercak atau karatan besi dan/atau mangan serta warna gley } \\
\text { (reduksi) pada lapisan } 0 \text { sampai } 25 \mathrm{~cm} \text {. }\end{array}$ \\
\hline 6 & $\begin{array}{l}\text { Terhambat } \\
\text { (poorly drained) }\end{array}$ & $\begin{array}{l}\text { Tanah mempunyai konduktivitas hidrolik rendah dan daya menahan air (pori } \\
\text { air tersedia) rendah sampai sangat rendah, tanah basah untuk waktu yang } \\
\text { cukup lama sampai ke permukaan. Tanah demikian cocok untuk padi sawah } \\
\text { dan sebagian kecil tanaman lainnya. Ciri yang dapat diketahui di lapangan, } \\
\text { yaitu tanah mempunyai warna gley (reduksi) dan bercak atau karatan besi } \\
\text { dan/atau mangan sedikit pada lapisan sampai permukaan. }\end{array}$ \\
\hline 7 & $\begin{array}{l}\text { Sangat terhambat } \\
\text { (very poorly drained) }\end{array}$ & $\begin{array}{l}\text { Tanah dengan konduktivitas hidrolik sangat rendah dan daya menahan air } \\
\text { (pori air tersedia) sangat rendah, tanah basah secara permanen dan tergenang } \\
\text { untuk waktu yang cukup lama sampai ke permukaan. Tanah demikian cocok } \\
\text { untuk padi sawah dan sebagian kecil tanaman lainnya. Ciri yang dapat } \\
\text { diketahui di lapangan, yaitu tanah mempunyai warna gley (reduksi) permanen } \\
\text { sampai pada lapisan permukaan. }\end{array}$ \\
\hline
\end{tabular}




\section{HASIL DAN PEMBAHASAN}

\section{Perhitungan Nilai Optimal untuk Masing- Masing Faktor (Tanah dan Iklim)}

Hasil persamaan regresi antara iklim dan tanah dengan produksi tanaman karet berdasarkan data sekunder hasil penelitian sebelumnya disajikan pada Tabel 2 dan 3.

Data iklim, terutama data hujan sangat penting dan dibutuhkan sebagai data dasar di dalam rangka evaluasi lahan untuk program pengembangan perkebunan karet maupun untuk menilai keragaan perkebunan karet yang telah ada. Terdapat beberapa macam batasan jumlah curah hujan, hari hujan, bulan kering, bulan basah, yang didefinisikan terbaik bagi tanaman karet di Indonesia. Hal ini menimbulkan kesan seolah-olah batasan karakteristik hujan kurang penting artinya bagi keberhasilan perkebunan karet serta membingungkan para pekebun dan praktisi perkebunan. Batasan-batasan tentang karakteristik hujan yang terbaik untuk karet tersebut kenyataannya belum didasarkan pada penelitian atau percobaan khusus (Darmandono, 1995).

Tabel 2. Persamaan regresi, nilai $r$, dan nilai optimal hubungan antara faktor iklim dengan produksi tanaman karet

Table 2. Regression equation, the value of $r$, and the optimal value of the relationship between climatic factors and rubber production

\begin{tabular}{|c|c|c|c|}
\hline $\begin{array}{l}\text { Parameter } \\
\text { Parameter }\end{array}$ & $\begin{array}{l}\text { Persamaan } \\
\text { Equation }\end{array}$ & $\begin{array}{c}\text { Koefisien } \\
\text { determinasi } \\
\text { Determination } \\
\text { coefficient }\end{array}$ & $\begin{array}{l}\text { Nilai optimal } \\
\text { Optimal value }\end{array}$ \\
\hline $\begin{array}{l}\mathrm{CH} \text { (mm/tahun) } \\
\text { dan produksi }\end{array}$ & $\begin{array}{l}\text { Produksi }= \\
8,0+1,122 \mathrm{CH}-0,000213 \mathrm{CH}^{2}\end{array}$ & 0,723 & $2640 \mathrm{~mm} /$ tahun \\
\hline $\begin{array}{l}\text { HH (hari/tahun) } \\
\text { dan produksi }\end{array}$ & $\begin{array}{l}\text { Produksi }= \\
-5459+101,5 \mathrm{HH}-0,3765 \mathrm{HH}^{2}\end{array}$ & 0,817 & 133 hari/tahun \\
\hline $\begin{array}{l}\text { BK (bulan/tahun) } \\
\text { dan produksi }\end{array}$ & $\begin{array}{l}\text { Produksi }= \\
432,9+791,8 \mathrm{BK}-153,0 \mathrm{BK}^{2}\end{array}$ & 0,713 & 3 bulan/tahun \\
\hline $\begin{array}{l}\text { ALT (m dpl) } \\
\text { dan produksi }\end{array}$ & $\begin{array}{l}\text { Produksi }= \\
930,9+4,527 \text { ALT } 0,01153 \mathrm{ALT}_{2}\end{array}$ & 0,359 & $168 \mathrm{~m} \mathrm{dpl}$ \\
\hline \multicolumn{4}{|c|}{$\begin{array}{l}\mathrm{CH}=\text { Curah hujan (Rainfall), } \mathrm{HH}=\text { Hari Hujan (Rainy days), } \mathrm{BK}=\text { Bulan kering (Dry month), } \\
\mathrm{ALT}=\text { Ketinggian (elevation) }\end{array}$} \\
\hline \multicolumn{4}{|c|}{$\begin{array}{l}\text { Tabel 3. Persamaan regresi, nilai r, dan nilai maksimal hubungan antara faktor tanah } \\
\text { dengan produksi tanaman karet } \\
\text { Table 3. Regresion equation, the value of } r \text {, and maximum value of the relationship between soil } \\
\text { factors and rubber production }\end{array}$} \\
\hline $\begin{array}{l}\text { Paramater } \\
\text { Parameter }\end{array}$ & $\begin{array}{l}\text { Persamaan } \\
\text { Equation }\end{array}$ & $\begin{array}{l}\text { Koefisien } \\
\text { determinan } \\
\text { Determination } \\
\text { coefficient }\end{array}$ & $\begin{array}{l}\text { Nilai optimal } \\
\text { Optimal value }\end{array}$ \\
\hline $\begin{array}{l}\text { CLY }(\%) \\
\text { dan produksi }\end{array}$ & $\begin{array}{l}\text { Produksi }= \\
203,8+70,73 \mathrm{CLY}-0,7746 \mathrm{CLY}^{2}\end{array}$ & 0,350 & $55 \%$ \\
\hline $\begin{array}{l}\text { DR } \\
\text { dan produksi }\end{array}$ & $\begin{array}{l}\text { Produksi }= \\
-2592+3032 \mathrm{DR}-530,1 \mathrm{DR}^{2}\end{array}$ & 0,254 & 3 \\
\hline
\end{tabular}

CLY $=$ Persentase lempung (Percentage of clay), DR = Drainase (Drainage) 


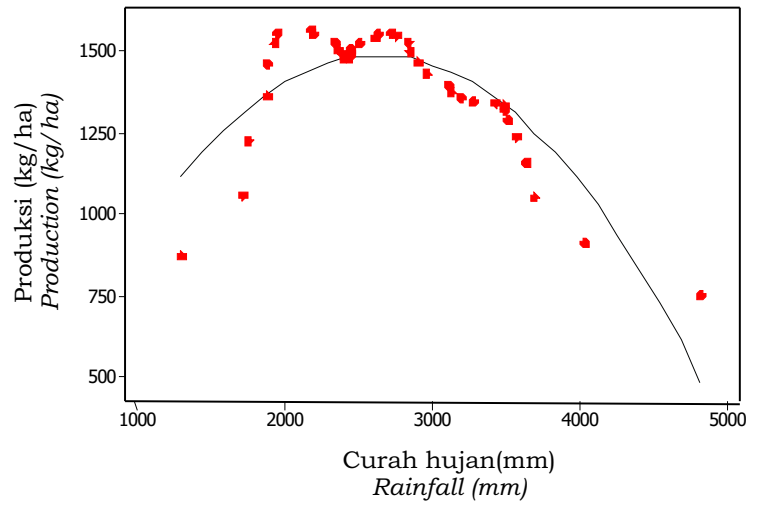

Gambar 1. Grafik hubungan curah hujan dan produksi tanaman karet

Figure 1. Relationship between rainfall and rubber production

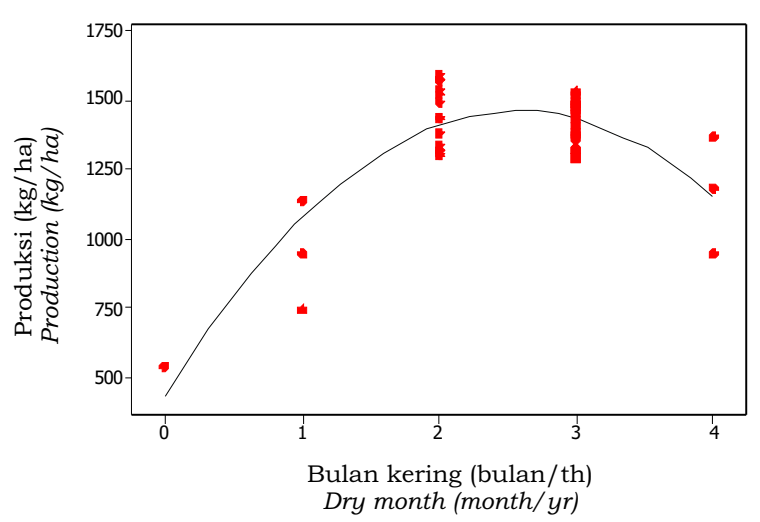

Gambar 3. Grafik hubungan bulan kering dan produksi tanaman karet

Figure 3. Relationship between dry month and rubber production

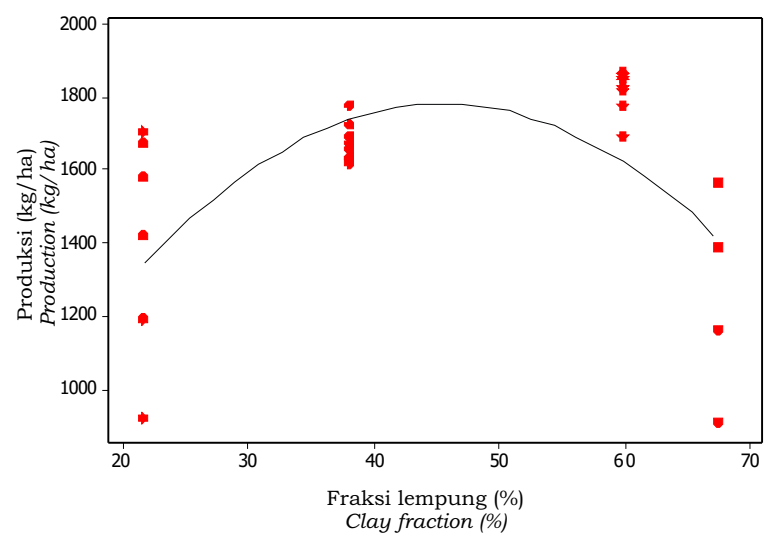

Gambar 5. Grafik hubungan persentase fraksi lempung dan produksi tanaman karet

Figure 5. Relationship between percentage clay fraction and rubber production

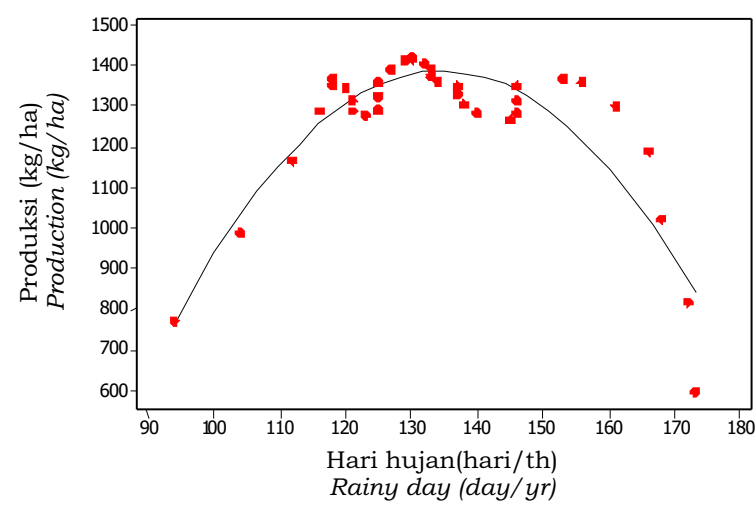

Gambar 2. Grafik hubungan hari hujan dan produksi tanaman karet

Figure 2. Relationship between rainy day and rubber production

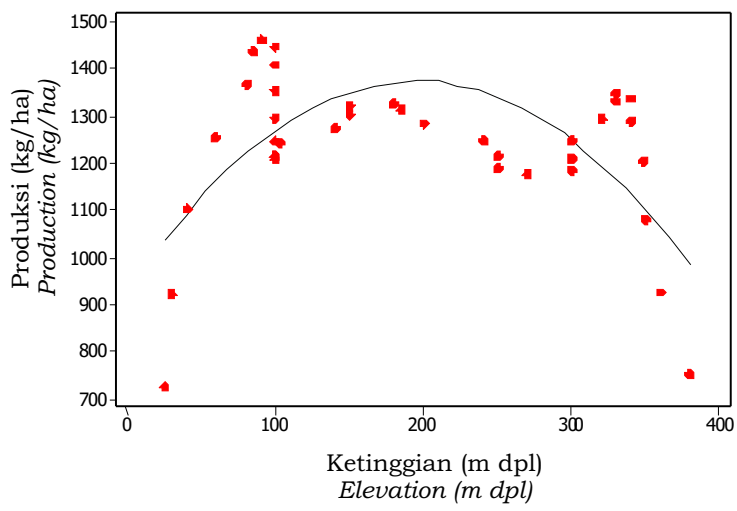

Gambar 4. Grafik hubungan ketinggian tempat dan produksi tanaman karet

Figure 4. Relationship between elevation and rubber production

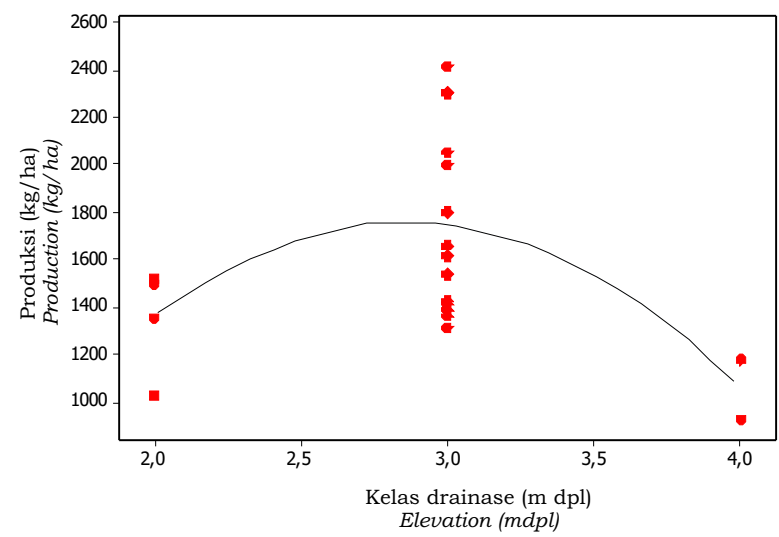

Gambar 6. Grafik hubungan kelas drainase tanah dan produksi tanaman karet

Figure 6. Relationship between soil drainage class and rubber production 
Hasil perhitungan nilai optimal dengan metode regresi kuadratik (Gambar $1 \mathrm{~s} / \mathrm{d}$ 6) menunjukkan bahwa curah hujan optimal adalah $2640 \mathrm{~mm} /$ tahun, dengan bulan kering per tahun adalah 3 bulan, serta hari hujan 133 hari, sedangkan untuk ketinggian optimal adalah $168 \mathrm{~m} \mathrm{dpl}$ (Tabel 1). Hal ini sejalan dengan pernyataan Djaenuddin et al. (1994) yang menerapkan kisaran curah hujan $2500-3000 \mathrm{~mm}$ sebagai batasan terbaik di dalam klasifikasi keserasian lahan untuk tanaman karet. Maas dan Bokma (1950) menyatakan kisaran hari hujan adalah 100 - 150 hari dan Sugiyanto et. al., (1998) berpendapat ketinggian tempat yang paling sesuai untuk tanaman karet adalah 0 - $200 \mathrm{~m}$ dpl. Nilai $\mathrm{r}$ pada masing-masing faktor terhadap produksi menunjukkan bahwa faktor iklim yang paling berpengaruh terhadap produksi secara berurutan adalah hari hujan $(0,817)$, curah hujan $(0,723)$, bulan kering $(0,713)$, dan ketinggian $(0,359)$.

Pada Tabel 2 faktor tanah menunjukkan bahwa nilai optimal kandungan lempung dalam tanah yang disukai tanaman karet adalah $55 \%$ dan drainase tergolong kelas 3 atau tanah dengan kelas drainase yang baik (well drained). Hal ini sedikit berbeda dengan pendapat Sugiyanto et al. (1998) yang menyebutkan kandungan fraksi lempung yang optimal untuk pertumbuhan tanaman karet adalah $10-40 \%$ sedangkan nilai diatas $50 \%$ tergolong sesuai. Tetapi untuk drainase berpendapat sama yaitu tanaman karet sesuai pada daerah dengan kondisi tanah yang berdrainase baik.

\section{Persamaan Estimasi Produksi Berdasarkan Faktor Produksi Tanaman, Iklim, dan Tanah}

Untuk mendapatkan tanaman karet dengan tingkat homogenitas yang tinggi perlu diperhatikan beberapa faktor pembatas yaitu heterogenitas atau keragaman tanah, tingkat juvenilitas mata okulasi yang digunakan, dan variabilitas batang bawah (Priyadarshan, 2007).

Persamaan produksi berdasarkan persamaan iklim dan tanah pada Tabel 2 dan 3 dibuat dengan mengasumsikan bahwa kondisi bahan tanam (entres) saat ini dibagi menjadi tiga kelas kualitas produktivitas yaitu Kualitas I (70\% dari potensi ortet), Kualitas II $(60 \%$ dari potensi ortet), dan Kualitas III (50\% dari potensi ortet). Hal ini dilakukan karena sesuai dengan pernyataan Darmandono (1996), bahwa mata okulasi yang digunakan secara komersial adalah tipe dewasa (mature type). Mata okulasi tersebut diambil dari batang bagian atas "seedling" cabang ortotrop atau batang yang telah melewati beberapa generasi mata okulasi (entres). Sifat batang atas yang berasal dari mata okulasi tipe dewasa tidak sama dengan yang berasal ortet "seedling" karena tidak mempunyai karakter juvenil. Oleh karena itu produksi dan kejaguran tanaman asal okulasi tipe dewasa belum tentu mempunyai korelasi yang tinggi dengan produksi dan kejaguran tanaman ortetnya. Selain itu hasil evaluasi Fewerda (1953) menunjukkan bahwa hasil okulasi yang bersumber dari mata okulasi juvenil (juvenile type) lebih rendah daripada ortetnya dengan nilai rerata produksi $70 \%$ dari ortetnya. Berdasarkan studi tersebut maka nilai potensi produksi klon GT 1 disajikan pada Tabel 4.

Berdasarkan nilai potensi produksi masing-masing klon pada Tabel 2 dan 3 persamaan produksi berdasarkan tanaman, iklim, dan tanah disajikan pada Tabel 5.

\section{Hasil Verifikasi Estimasi Produksi di Lapangan}

Pengaruh tanah dan iklim terhadap produktivitas tanaman karet telah banyak

Tabel 4. Nilai potensi produksi klon GT 1 berdasarkan kualitas kayu okulasi/entres Table 4. Potential value of clone GT 1 production based on budwood quality

\begin{tabular}{cccc}
\hline $\begin{array}{c}\text { Klon } \\
\text { Clone }\end{array}$ & $\begin{array}{c}\text { Kualitas I } \\
\text { First quality } \\
\mathrm{kg} / \text { ha/siklus }\end{array}$ & $\begin{array}{c}\text { Kualitas II } \\
\text { Second quality } \\
\mathrm{kg} / \text { ha/siklus }\end{array}$ & $\begin{array}{c}\text { Kualitas III } \\
\text { Third quality } \\
\mathrm{kg} / \mathrm{ha} / \mathrm{siklus}\end{array}$ \\
\hline GT 1 & 1379 & 1013 & 844 \\
\hline
\end{tabular}


diteliti dan nyata berpengaruh terhadap pencapaian produksi (Jiang, 1988, Rao et. al., 1998, Priyadarshan, 2003a, Raj et al., 2005, Rao et al., 2007). Titik berat utama penelitian adalah faktor iklim karena merupakan faktor utama yang mempengaruhi produksi tanaman karet. Hal ini sesuai dengan yang diutarakan oleh Sugiyanto et al. (1998) bahwa iklim merupakan komponen lahan yang tidak dapat dimodifikasi. Nilai persentase iklim pada penelitian menunjukkan angka yang lebih tinggi dibandingkan dengan faktor tanah yaitu berturut-turut $81,91 \%$ dan $18,78 \%$ (Tabel 6). Hal ini menunjukkan bahwa dengan mengetahui faktor iklim, maka potensi produksi tanaman karet di suatu wilayah sudah dapat diduga yaitu kurang lebih $80 \%$ dari nilai estimasi. Model perhitungan potensi produksi per siklus klon GT 1 disajikan pada Tabel 7.

Penentuan daerah yang digunakan untuk verifikasi adalah Perusahaan Perkebunan Negara di Propinsi Jawa Barat, Jawa Tengah, dan Jawa Timur yang menanam klon GT1. Pemilihan kebun ini berdasarkan informasi bahwa pola sadapan dan pemeliharaan tanaman dilakukan standar (Sudiharto et. al., 2008). Karateristik tanah dan iklim pada masing-masing kebun disajikan pada Tabel 8.

Pemilihan perwakilan kebun diatas didasarkan pada ketersediaan data dengan data tanah yang ada di Balai Penelitian Getas. Hasil perbandingan produksi estimasi dan realita tersebut disajikan pada Tabel 9.

Implikasi adaptasi secara genetik akan membentuk populasi dengan spesifik spesies yang mampu merespons pada lingkungan. Dua komponen lahan secara abiotik adalah iklim dan tanah. Kedua faktor ini merupakan faktor utama yang membentuk adaptabilitas suatu tanaman. Distribusi tanaman secara geografis dan ekologi dengan karateristik fisiologi yang berbeda akan membentuk pola adaptabilitas tanaman terhadap tanah dan iklim (Vega,1996). Produksi tanaman karet dipengaruhi oleh beberapa faktor. Azwar et al. (2000) menyebutkan bahwa produksi tanaman karet pada suatu wilayah tertentu dipengaruhi oleh tiga faktor utama yaitu faktor potensi genetik bahan tanam (genetic potential of planting material $(G)$ ), lingkungan (environment $(E)$, dan interaksi antara faktor genetik dan lingkungan (interaction between planting material and location (GE).

Hasil perhitungan estimasi poduksi (Tabel 9) merupakan hasil interaksi antara potensi produksi klon, iklim, dan tanah. Hasil akurasi antara produksi estimasi dan realita menunjukkan berturut turut dari entres kualitas I, II, dan III adalah 79,19\%, 69,39\%, dan 56,77\%. Hasil menunjukkan bahwa perhitungan yang sesuai pada ketiga

Tabel 5. Persamaan potensi produksi klon GT 1 berdasarkan faktor tanah dan iklim

Table 5. Potential equation of clone GT 1 production based on soil factor and climate

\begin{tabular}{|c|c|c|c|}
\hline \multirow[b]{2}{*}{$\begin{array}{l}\text { Klon } \\
\text { Clone }\end{array}$} & \multirow{2}{*}{$\begin{array}{l}\text { Kualitas } \\
\text { entres } \\
\text { Budwood } \\
\text { quality }\end{array}$} & \multicolumn{2}{|r|}{$\begin{array}{l}\text { Faktor } \\
\text { Factor }\end{array}$} \\
\hline & & $\begin{array}{c}\text { Iklim } \\
\text { Climate } \\
\mathrm{kg} / \mathrm{ha} / \text { siklus }\end{array}$ & $\begin{array}{l}\text { Tanah } \\
\text { Soil } \\
\mathrm{kg} / \mathrm{ha} / \text { siklus }\end{array}$ \\
\hline \multirow{3}{*}{ GT 1} & $\begin{array}{l}\text { Kualitas } \\
\text { I }\end{array}$ & $\begin{array}{l}\text { PCH1 }=7,1+0,9873 \mathrm{CH}-0,000187 \mathrm{CH}^{2} \\
\text { PHH1 }=-5294+98,47 \mathrm{HH}-0,3651 \mathrm{HH}^{2} \\
\text { PBK1 }=375,7+687,1 \mathrm{BK}-132,8 \mathrm{BK}^{2} \\
\text { PALT } 1=878,1+4,270 \mathrm{ALT}-0,01088 \mathrm{ALT}^{2}\end{array}$ & $\begin{array}{l}\text { PCLY1 }=149,5+51,88 \mathrm{CLY}-0,5681 \mathrm{CLY}^{2} \\
\text { PDR1 }=-1481+1732 \mathrm{DR}-302,8 \mathrm{DR}^{2}\end{array}$ \\
\hline & Kualitas II & $\begin{array}{l}\text { PCH2 }=6,0+0,8463 \mathrm{HH}-0,000160 \mathrm{HH}^{2} \\
\text { PHH2 }=-3889+72,35 \mathrm{HH}-0,2683 \mathrm{HH}^{2} \\
\text { PBK2 }=276,0+504,8 \mathrm{BK}-97,55 \mathrm{BK}^{2} \\
\text { PALT } 2=645,1+3,137 \mathrm{ALT}-0,007992 \mathrm{ALT}^{2}\end{array}$ & $\begin{array}{l}\text { PCLY2 }=103,5+35,93 \text { CLY }-0,3935 \mathrm{CLY}^{2} \\
\text { PDR2 }=-1088+1273 \mathrm{DR}-222,5 \mathrm{DR}^{2}\end{array}$ \\
\hline & Kualitas III & $\begin{array}{l}\text { PCH3 }=4,3+0,6045 \mathrm{CH}-0,000115 \mathrm{CH}^{2} \\
\text { PHH3 }=-3241+60,29 \mathrm{HH}-0,2235 \mathrm{HH}^{2} \\
\text { PBK3 }=230,0+420,7 \mathrm{BK}-81,30 \mathrm{BK}^{2} \\
\text { PALT3 }=537,6+2,614 \text { ALT }-0,006660 \mathrm{ALT}^{2}\end{array}$ & $\begin{array}{l}\text { PCLY3 }=68,9+23,91 \text { CLY }-0,2618 \text { CLY }^{2} \\
\text { PDR3 }=-906,6+1061 \mathrm{DR}-185,4 \mathrm{DRN}^{2}\end{array}$ \\
\hline
\end{tabular}


Tabel 6. Nilai persentase terhadap nilai koefisien determinan total masing-masing faktor Table 6. Percentage value of total determinant coefficient on each factor

\begin{tabular}{|c|c|c|}
\hline $\begin{array}{l}\text { Faktor } \\
\text { Factor }\end{array}$ & $\begin{array}{l}\text { Koefisien determinan } \\
\text { Determinant coefficient }\end{array}$ & $\begin{array}{c}\text { Persentase terhadap nilai koefisien } \\
\text { determinan total } \\
\text { Percentage of total determinant } \\
\text { coefficient } \\
\%\end{array}$ \\
\hline Curah hujan (mm/tahun) & 0,723 & 22,48 \\
\hline Hari hujan (hari/tahun) & 0,817 & 25,40 \\
\hline Bulan Kering (bulan/tahun) & 0,713 & 22,17 \\
\hline Ketinggian tempat (m dpl) & 0,359 & 11,16 \\
\hline \multicolumn{2}{|c|}{ Total Iklim } & 81,91 \\
\hline $\begin{array}{l}\text { Persentase lempung (\%) } \\
\text { Drainase }\end{array}$ & 0,350 & 10,88 \\
\hline \multicolumn{2}{|c|}{ Total Tanah } & 18,78 \\
\hline Total & 3,21 & 100 \\
\hline
\end{tabular}

Tabel 7. Model perhitungan produksi tanaman karet klon GT 1

Table 7. Calculation model of rubber production of clone GT 1

\begin{tabular}{|c|c|c|}
\hline $\begin{array}{l}\text { Klon } \\
\text { Clone }\end{array}$ & $\begin{array}{l}\text { Kualitas } \\
\text { entres } \\
\text { Budwood } \\
\text { quality }\end{array}$ & $\begin{array}{l}\text { Perhitungan produksi } \\
\text { Production calculation } \\
\text { kg/ha/siklus }\end{array}$ \\
\hline \multirow{3}{*}{ GT 1} & Kualitas I & GT $1=(\mathrm{PCH} 1 * 22,48)+(\mathrm{PHH} 1 * 25,40)+(\mathrm{PBK} 1 * 22,17)+(\mathrm{PALT} 1 * 11,16)+(\mathrm{PCLY} 1 * 10,88)+(\mathrm{PDR} 1 * 7,90)$ \\
\hline & Kualitas II & GT $1=($ PCH $2 * 22,48)+($ PHH2 25,40$)+\left(\mathrm{PBK}^{*} * 22,17\right)+(\mathrm{PALT} 2 * 11,16)+\left(\mathrm{PCLY}^{*} * 10,88\right)+(\mathrm{PDR} 1 * 7,90)$ \\
\hline & Kualitas III & GT $1=\left(\right.$ PCH$\left.^{*} 22,48\right)+\left(\right.$ PHH3 $\left.^{*} 25,40\right)+\left(\right.$ PBK3 $\left.^{*} 22,17\right)+\left(\right.$ PALT $\left.1 *^{*} 11,16\right)+\left(\right.$ PCLY3 $\left.^{*} 10,88\right)+($ PDR $1 * 7,90)$ \\
\hline
\end{tabular}

Tabel 8. Karateristik tanah dan iklim masing-masing kebun Table 8. Characteristic of soil and climate on each estate

\begin{tabular}{lccc}
\hline \multicolumn{1}{c}{$\begin{array}{c}\text { Parameter } \\
\text { Parameter }\end{array}$} & $\begin{array}{c}\text { Kebun A } \\
\text { (Jawa Barat) } \\
\text { Estate A, West Java }\end{array}$ & $\begin{array}{c}\text { Kebun B } \\
\text { (Jawa Tengah) }\end{array}$ & $\begin{array}{c}\text { Kebun C } \\
\text { (Jawa Timur) }\end{array}$ \\
\hline $\begin{array}{l}\text { Ketinggian (m dpl) } \\
\text { Eurah hujan } \\
\text { (mm/tahun) }\end{array}$ & 115 & 480 & 400 \\
$\begin{array}{l}\text { Hari hujan (hari/tahun) } \\
\text { Bulan kering } \\
\text { (bulan/tahun) }\end{array}$ & 3001 & 2401 & 3320 \\
Persentase lempung (\%) & 100 & 119 & 150 \\
Tingkat Drainase (Kelas) & 2,75 & 2 & 2,7 \\
\hline
\end{tabular}


Tabel 9. Hasil prediksi dan realita produksi tanaman karet klon GT 1 di Perkebunan Negara di Pulau Jawa

Table 9. Prediction and actual rubber production of clone GT 1 at Government-Owned Estates in Java

\begin{tabular}{|c|c|c|c|c|c|c|c|c|}
\hline \multirow[t]{2}{*}{$\begin{array}{l}\text { Kebun } \\
\text { Estate }\end{array}$} & \multirow[t]{2}{*}{$\begin{array}{c}\text { Umur } \\
\text { tanaman } \\
(\mathrm{Th}) \\
\text { Crop Age } \\
(\mathrm{Yr})\end{array}$} & \multicolumn{3}{|c|}{$\begin{array}{c}\text { Produksi estimasi } \\
\text { Estimate production } \\
\mathrm{kg} / \mathrm{ha} / \mathrm{th} \\
\mathrm{kg} / \mathrm{ha} / \mathrm{yr}\end{array}$} & \multirow[t]{2}{*}{$\begin{array}{c}\text { Produksi realita } \\
\text { Reality production } \\
\mathrm{kg} / \mathrm{ha} / \mathrm{th}^{1} \\
\mathrm{~kg} / \mathrm{ha} / \mathrm{yr}\end{array}$} & \multicolumn{3}{|c|}{$\begin{array}{c}\text { Tingkat akurasi } \\
\text { estimasi dan realita } \\
\text { Accuration estimation } \\
\text { and reality } \\
\%\end{array}$} \\
\hline & & $\mathrm{KI}$ & KII & KIII & & $\mathrm{KI}$ & KII & KIII \\
\hline \multirow{5}{*}{ Kebun A } & 14 & 1616,12 & 1315,47 & 1049,07 & 1815 & 89,04 & 72,48 & 57,80 \\
\hline & 15 & 1606,38 & 1305,80 & 1041,36 & 1705 & 94,22 & 76,59 & 61,08 \\
\hline & 16 & 1596,65 & 1296,13 & 1033,65 & 2109 & 75,71 & 61,46 & 49,01 \\
\hline & 17 & 1557,71 & 1257,44 & 1002,79 & 1699 & 91,68 & 74,01 & 59,02 \\
\hline & 18 & 1489,56 & 1209,08 & 964,22 & 1555 & 95,79 & 77,75 & 62,01 \\
\hline \multicolumn{6}{|c|}{ Rerata Jawa Barat } & 89,29 & 72,46 & 57,78 \\
\hline \multirow{6}{*}{ Kebun B } & 11 & 1135,95 & 991,53 & 783,58 & 1501 & 75,68 & 66,06 & 52,20 \\
\hline & 12 & 1270,20 & 1087,49 & 859,41 & 2187 & 58,08 & 49,73 & 39,30 \\
\hline & 13 & 1373,47 & 1151,46 & 909,96 & 1829 & 75,09 & 62,96 & 49,75 \\
\hline & 14 & 1404,45 & 1183,44 & 935,24 & - & - & - & - \\
\hline & 15 & 1394,12 & 1183,44 & 935,24 & 1899 & 73,41 & 62,32 & 49,25 \\
\hline & \multicolumn{4}{|c|}{ Rerata Jawa Tengah } & & 70,57 & 60,26 & 47,63 \\
\hline \multirow{5}{*}{ Kebun C } & 12 & 1316,39 & 1082,97 & 865,94 & 1056 & 75,34 & 97,45 & 82,00 \\
\hline & 13 & 1443,78 & 1210,96 & 968,28 & 1025 & 59,14 & 81,86 & 94,47 \\
\hline & 14 & 1528,71 & 1309,41 & 1047,00 & 1695 & 90,19 & 77,25 & 61,77 \\
\hline & 15 & 1571,18 & 1338,95 & 1070,62 & 1748 & 89,88 & 76,60 & 61,25 \\
\hline & 16 & 1571,18 & 1329,11 & 1062,75 & 1837 & 85,53 & 72,35 & 57,85 \\
\hline \multicolumn{6}{|c|}{ Rerata Jawa Timur } & $\mathbf{7 7 , 7 2}$ & 75,44 & 64,89 \\
\hline \multicolumn{6}{|c|}{ Total Rerata } & 79,19 & 69,39 & 56,77 \\
\hline
\end{tabular}

${ }^{1}$ diambil dari formulir lembar LSU tahun 2006 - 2008, (taken from LSU 2006 - 2008)

(-) tidak ada data (no data available)

(KI) entres Kualitas 1 (Budwood quality 1)

(K II) entres Kualitas 2 (Budwood quality 2)

(K III) entres Kualitas 3 (Budwood quality 3)

perkebunan tersebut diatas adalah model perhitungan untuk entres dengan Kualitas I. Sehingga dapat dikatakan bahwa di ketiga kebun tersebut entres yang digunakan adalah entres kualitas satu (potensi fisiologis kelas 1) dengan rerata produksi per siklus adalah $1379 \mathrm{~kg} / \mathrm{ha} /$ siklus dengan asumsi siklus tanaman karet adalah 30 tahun dan penggunaan kulit sadapan adalah 25 tahun. Hasil estimasi didasarkan pada asumsi bahwa faktor-faktor lain seperti pemeliharaan (konservasi tanah, pengendalian gulma, pemupukan, pengendalian penyakit) dan pola penyadapan berjalan sesuai norma.

Azwar et al. (2000) berpendapat bahwa tanpa perlakuan pemeliharaan dan sadapan yang tepat menyebabkan kehilangan produksi sekitar $10-30 \%$. Selain itu pemilihan lahan dengan kondisi tekstur yang memadai merupakan syarat utama tumbuh tanaman karet. Pada tekstur berat, tingkat drainase akan cenderung terhambat, sedangkan bila terlalu ringan maka drainasenya cenderung cepat. Djikman (1950) mengatakan bahwa tanaman karet secara umum tumbuh baik pada tanahtanah yang dalam dengan tingkat aerasi yang baik, tetapi tanaman ini dilaporkan juga tumbuh pada tanah-tanah tergenang. Ritung et. al., (2007) mengemukakan bahwa kelas drainase tanah yang sesuai untuk sebagian besar tanaman, terutama tanaman tahunan atau perkebunan berada pada kelas 3 dan 4. Drainase tanah kelas 1 dan 2 serta kelas 5, 6, dan 7 kurang sesuai untuk tanaman tahunan karena kelas 1 dan 2 mudah sekali meloloskan air sedangkan 5, 6 , dan 7 sering jenuh air dan kekurangan 
oksigen. Hasil penelitian lain menyebutkan bahwa tanaman karet seedling pada kondisi tanah dengan tingkat drainase yang jelek (tergenang) menyebabkan pertumbuhan daun terhambat, kandungan klorofil menurun, meningkatkan produksi acethylene, dan terhambatnya pertumbuhan tanaman. Pengunaan klon tertentu yang tahan terhadap genangan merupakan suatu terobosan yang dapat dilakukan (Gomes et al., 1988).

\section{KESIMPULAN}

Berdasarkan hasil dan pembahasan diatas dapat disimpulkan sebagai berikut :

1. Nilai optimal pertumbuhan tanaman karet untuk faktor iklim adalah curah hujan $2640 \mathrm{~mm} /$ tahun, bulan kering 3 bulan/tahun, hari hujan 133 hari/tahun, dan ketinggian optimal adalah $168 \mathrm{~m}$ dpl, sedangkan untuk faktor tanah 55\% kandungan fraksi lempung dan drainase tergolong kelas 3 (well drained).

2. Produksi tanaman karet sangat dipengaruhi oleh faktor tanah dan iklim dengan persentase berturut-turut adalah $81,91 \%$ dan $18,78 \%$.

3. Persamaan khusus pada klon GT1 berdasarkan kajian diatas adalah persamaan dengan asumsi kualitas mata entres adalah kualitas 1 dengan model persamaan yaitu : GT $1=$ $(\mathrm{PCH} 1 * 22,48)+(\mathrm{PHH} 1 * 25,40)+(\mathrm{PBK} 1 * 22$, $17)+($ PALT $1 * 11,16)+($ PCLY $1 * 10,88)+(\mathrm{PD}$ $\mathrm{R} 1 * 7,90)$

4. Tingkat akurasi model terhadap hasil produksi di lapangan adalah 79,19\%.

\section{DAFTAR PUSTAKA}

Aidi-Daslin, I. Suhendry, dan R. Azwar. 1997. Produktivitas perkebunan karet dalam hubungannya dengan jenis klon dan agroklimat. Pros. Apresiasi Teknologi Peningkatan Produktivitas Lahan Perkebunan Karet, Medan. Pusat Penelitian Karet Medan.
Azwar, R., Aidi-Daslin, I. Suhendry, and S. Woelan, 2000. Quantifiying genetical and environment factors in determining rubber crop productivity. Proc. Indonesian Rubb. Conf. and IRRDB Symposium. Indonesian Rubber Research Institute. Vol. 1, 143-149.

Budiman, A.F.S. 2005. Prospek pasar dan produksi karet Indonesia. Pusat Penelitian Karet.

Ceccarelli, S. 1994. Specific adaptation and breeding for marginal conditions. Euphytica 77, 205-219.

Chan, H.Y., C.B. Wong, K. Sivanadyan, and E. Pushparajah. 1974. Influence of soil morphologhy and physiography on leaf nutrient content and performance of Hevea. Proc. Rubb. Res. Inst. Malaysia Plrs' Conf. Kuala Lumpur.

Darmandano. 1993. Peluang peningkatan produksi karet (Hevea brasiliensis) : mendekatkan potensi produksi klon ke arah potensi produksi ortetnya melalui rejuvenasi. Jurnal Litbang Pertanian, XII (3).

Darmandono. 1981. Survei tanah terperinci kebun Sumber Ayu PTP XXIX. Research Centre Getas. Salatiga.

Darmandono. 1995. Pengaruh komponen hujan terhadap produktivitas karet. J. Penel. Karet. 13(3), 223-233.

Darmawijaya, I. 1968. Laporan pemetaan tanah Kebun Batudjamus dan Kerjogadungan P.N.P. XVIII. Perusahaan Negara Perkebunan. Rubber Research Centre, Getas. Salatiga.

Darmawijaya, I. 1970. Laporan pemetaan tanah Perkebunan Batu Lawang P.N.P. XIII. Perusahaan Negara Perkebunan. Rubber Research Centre, Getas. Salatiga. 
Darwis, S. N. 1992. Pengaruh kemarau panjang dan usaha mengatasinya pada tanaman perkebunan. Lokakarya kiat menghadapi kemungkinan kemarau panjang 1992 untuk tanaman perkebunan. Bandung, Februari 1992.

Dea, B.G., A.A, Assiri, R.O. Gabla, and D. Boa. 2001. Influence of soil preparation method on root and vegetative growth of rubber tree (Hevea brasiliensis) in Southwast Cote de Ivore. Soil and Tillage Research. 3 (11).

Dijkman, M.J. 1951. Hevea. Thirty Years of Research in the Far East. University of Miami Press. Corral Gables, Florida, USA.

Djaenuddin, D., S. Basuni, S. Harjowigeno, H. Subagyo, Sukardi, Ismangun, Marsudi Ds, N. Suharta, L. Hakim, Widagdo, J. Dai, V. Suwandi, S. Bachri, dan E.R. Jordens. 1994. Kesesuaian lahan untuk tanaman pertanian dan tanaman kehutanan. Laporan Teknis No. 7 Versi 1.0. Pusat Penelitian Tanah dan Agroklimat, Bogor, $50 \mathrm{p}$.

Ferwerda, F.P. 1953. A possible explanation of the divergence between juvenile type budgrafts and their seedling mother trees in Hevea. Euphytica, (2), 15-24.

Gomes, A. R. S., and T. T. Kozlowski. 1988. Physiological and growth responses to flooding of seedlings of Hevea brasiliensis. Biotropica 20(4), 286293.

Jiang, A. 1988. Climate and natural production of rubber (Hevea brasiliensis) in Xishuangbanna, southern part of Yunnan province, China (Short communication). Int. J. Biometeorol. 32, 280-282.

Maas, J.G.J.A, and T. Bokma. 1950. Rubbercultuur der Ondenemingen. dalam: De Landbouw in de Indische
Archipel (Edit. C.J.J. Van Hall en C. Van De Koppel. Dell III, N.V. Uitgeverij W. Van Hoeve, S-Gravenhage, 237 426.

Priyadarshan, P.M. 2003a. Contributions of weather variables for specific adaptation of rubber tree (Hevea brasiliensis Muell.- Arg) clones. Genetics and Molecular Biology, 26 (4), 435-440.

Priyadarshan, P.M. 2003b. Breeding Hevea brasiliensis for environmental constraints. Advances in Agronomy, 79, 351-400.

Priyadarshan, P.M. 2007. Genome Mapping and Molecular Breeding in Plants, Volume 6 Technical Crops. Kole (Ed.). Springer-Verlag Berlin. Heidelberg.

Raj, S. Das, G. Pothen, J. Sushi, and K. Dey. 2005. Relationship between latex yield of Hevea brasiliensis and antecedent environmental parameters. Int. J. Biometeorol. 49, 189-196.

Rao, S.J., C.K. Saraswathyamma, and M.R. Sethuraj. 1998. Studies on the relationship between yield and meteorological parameters of para rubber tree (Hevea brasiliensis). Agricultural and Forest Meteorology. 90, 235-245.

Rao G. G., P. Sanjeeva Rao, R. Rajagopal, A.S. Devakumar, K.R. Vijayakumar, and M.R. Sethuraj. 1990. Influence of soil, plant and meteorological factors on water relations and yield in Hevea brasiliensis. Int. J. Biometeorol, 1990 34, 175-180.

Rao, D.V.K. N. and M.D. Jessy. 2007. Impact of effective soil volume on growth and yield of rubber (Hevea brasiliensis). Geoderma, 141, 332-340.

Ritung, S. Wahyunto, Agus, dan F. H. Hidayat .2007. Evaluasi kesesuaian lahan dengan contoh peta arahan penggunaan lahan Kabupaten Aceh Barat. Balai Penelitian Tanah dan World Agroforestry Centre. 
Schmidth, F.H. and J.H.A. Fergusson. 1951.Rainfall types based on wet and dry period ratios for Indonesia with Western New Guinee. Verhandelingen No. 42. Kementerian Perhubungan, Jawatan Meteorologi dan Geofisik, Jakarta, 77 p.

Sudiharto. 2004. Kelayakan penerapan metode oldeman untuk klasifikasi tipe curah hujan di perkebunan karet. J. Penel. Karet, 22 (2), 23-35.

Sudiharto, Setiono, dan H. Hadi. 2008. Komunikasi Pribadi. Balai Penelitian Getas. Salatiga.

Sugiyanto, Y., Sihombing, dan H., Darmandono. 1998. Pemetaan agroklimat dan tingkat kesesuaian lahan perkebunan karet. Pros. Lok. Nas. Pemuliaan Karet 1998 dan Diskusi Nasional Prospek Karet Alam Abad 21, Medan, 8-9 Desember 1998. Pusat Penelitian Karet Medan.

Sutardi. 1974. Tingkat keuntungan perusahaan perkebunan karet di Jawa. Risalah Penelitian RC Getas. Rubber Research Centre, Getas. Salatiga.
Tang, H. and E. Van Ranst. 1992. Testing of fuzzy set theory in land suitability assessment for rainfed gram maize production. Pedologie, XLII-2, 129147.

Williams, C.N. and K.T. Joseph. 1974. Climate, Soil, and Crop Production In The Humid Tropics. Rv. Ed. 2nd. Imp. Oxford University Press London. Kuala Lumpur.

Yew. F.K., and E. Pushparajah. 1991. Influence of soil conditions on growth of Hevea : Glasshouse evaluations. $J$. Nat. Rubb. Res., 6(1), 62-73.

Van Ranst, E., H. Tang, Groenemans, and R.S. Sinthurahat. 1997. Application of fuzzy logic to land suitability for rubber production in peninsular Thailand. Geodema, 70, 1-19.

Vega, M. P. 1996. Plant genetic adaptedness to climatic and edaphic environment. Euphytica, 92, 27-38. 